\title{
BADANIA ARCHEOLOGICZNE DWORU ZAREMBÓW W KALINOWEJ - SIEDZIBY JEDNEGO Z NAJZAMOŻNIEJSZYCH RODÓW W ŚREDNIOWIECZNEJ POLSCE
}

SŁowa KLuCzowe: Zarembowie, Kalinowa, badania archeologiczne, badania architektoniczne, średniowiecze, nowożytność, architektura obrona, dwór

KEywords: Zarembowie, Kalinowa, archaeological excavations, architectural researches, medieval, post-medieval, hillfort, military architecture

W październiku 2011 r. przy dworze w Kalinowej, gm. Błaszki, wspólnie z Januszem Pietrzakiem, przeprowadziliśmy niewielkie sondażowe badania archeologiczne zmierzające do rozpoznania stratygrafii nawarstwień ziemnych przy dworze i uchwycenia ewentualnych reliktów starszej zabudowy murowanej lub drewnianej. Prace archeologiczne realizowane były symultanicznie do badań architektonicznych kierowanych przez Pawła Filipowicza z łódzkiego oddziału Narodowego Instytutu Dziedzictwa, a lokalizacja wykopów ściśle związana była z odkryciami w obrębie obiektu.

W trakcie prac wytyczyliśmy zaledwie dwa wykopy (nr 1 i 2) o łącznej powierzchni $15 \mathrm{~m}^{2}$, z których pierwszy usytuowany został po północnej stronie dworu, przy wschodnim narożniku ryzalitu. Jego wymiary pierwotne wynosiły 2 x 3 m (2 m w linii północ - południe), po czym w związku z poczynionymi odkryciami, został powiększony w kierunku północnym wykopem o szerokości 1,3 m w linii wschód - zachód i długości 5 m w linii północ - południe w taki sposób, że obydwa wykopy posiadały wspólny zachodni profil, którego łączna długość wynosiła $6,5 \mathrm{~m}$.

Wykop nr 2 (2 x $1 \mathrm{~m}$ ) ulokowany został przy południowo-wschodniej przyporze dworu, tak aby uchwycić ewentualną kontynuację ściany wschodniej poza obecnym obrysem bryły, na co wskazywały obserwacje architektoniczne wewnątrz obiektu. 
Ponadto, wykonano niewielki sondaż w narożniku południowo-wschodniej przypory ze ścianą południową dworu, w celu wykonania obserwacji architektonicznych.

\section{TŁo HISTORYCZNE ORAZ STAN BADAŃ}

Dzisiejszy obiekt, zarówno z uwagi na stan zachowania jak i lokalizację w obrębie niewielkiej miejscowości, nie sprawia obecnie imponującego wrażenia. Jak bardzo jest to mylące pokazały nie tylko wyniki badań archeologicznych i architektonicznych, ale także niezwykle wyczerpująca kwerenda historyczno-archiwalna wykonana przez Xenię Modrzejewską-Mrozowską (Modrzejewska-Mrozowska i in. 2011), której niewielką część dla zobrazowania tła badawczego należy tutaj przytoczyć.

Prace badawcze na obiekcie zapoczątkowane zostały przez Zofię Białłowicz-Krygierową w latach 1955 i 1961, czego efektem było powstanie studium historyczno-architektonicznego (Białłowicz-Krygierowa 1957). W roku 1988 zespół archeologów przeprowadził weryfikacyjne badania archeologiczne skupiające się przede wszystkim na wyspie znajdującej się na północ od budynku dworu (Głosek i in. 1988).

W efekcie tychże prac, ustalono że najstarsze nawarstwienia i zabytki odkryte w wykopie usytuowanym na wyspie datować można na okres późnego średniowiecza (Głosek i in. 1988: 21). Istniała tam zapewne wybudowana w XV w. siedziba rodu Zarembów, która z czasem została opuszczona na korzyść obszaru zajmowanego przez obecnie istniejące założenie dworskie. W trakcie prac nie natrafiono na obiekty o starszej chronologii, co może wskazywać, iż mamy do czynienia z fundacją na surowym korzeniu.

Próba zrozumienia istoty badanego przez nas stanowiska musi się rozpocząć od przytoczenia najważniejszych faktów z historii miejscowości oraz personaliów właścicieli, wśród których nie brak osób pełniących ważne funkcje nie tylko w skali lokalnej, ale i całego kraju:

- Arkembold (zm. po 1370), syn Sędziwoja z Pątnowa - pierwszy z Zarembów określany przydomkiem „z Kalinowy”;

- pierwsza pisana wzmianka o Kalinowej pochodzi z 1370 r. - mowa tu o dokumencie wystawionym przez Boguchwała dziedzica Szkudły, w którym w roli świadka występuje Arkembold heres de Kalinowa (Dworzaczek 2004);

- Marcin Zaremba z Kalinowy, syn Arkembolda (zm. po 1434 lub 1438), chorąży sieradzki (1395, 1398/1399), kasztelan sieradzki (1399, 1401/1429), wojewoda sieradzki (1430, 1431/1437), kasztelan/starosta wieluński (1416-1426/1430), uczestnik rad wojennych; 
- Wawrzyniec Zaremba z Kalinowy, syn Marcina (zm. 1453/1454), marszałek dworu królewskiego (1420/1421-1425/1426, 1422-1425), marszałek koronny (1425/1426-1430), kasztelan sieradzki (1431-1451/1452), wojewoda sieradzki (1453), starosta wieluński (1431/1432-1452/1453) i ostrzeszowski (1450-1453), tenutariusz grabowski;

- Jan Zaremba z Kalinowy zwany „Łopatą” lub „Łopacicem”, syn Marcina (zm. przed 1451, 1457/1458), kasztelan sanocki (1435, 1435-1457);

- Jan Zaremba z Kalinowy, syn Wawrzyńca (zm. przed 1485, 1481?), starosta ostrzeszowski (1445-1447 oraz 1453-1458) i wieluński (1453-1479), kasztelan sieradzki (1461-1477), wojewoda łęczycki (1478), wojewoda sieradzki i kaliski (1477-1479);

- jego syn, również Jan Zaremba z Kalinowy (zm. około 1525), dworzanin królewski (1493), starosta generalny Wielkopolski (1504-1508), kasztelan poznański (1508), wojewoda łęczycki (1511), wojewoda kaliski (1512), starosta sieradzki, grabowski i człuchowski;

- w dokumencie z 1537 r. podana jest informacja o tym, że Wacław Zaremba z Kalinowy, syn Jana, jest dziedzicem „1/2 wsi Kalinowa”. Teki Dworzaczka... (2004: poz. 200, 1044) podają zapis z roku 1544 dotyczący podziału majątku między braci Zarembów:

Wacław Zaremba klan nakiel. i Stanisław Z. bracia rodzeni okazują działy: Krzysztof, Jan i Wacław ZZ. dziedzice z Kalinowy czynią działy. [...]. Wacław - Kalinowa i wsie: Domanów, Tuwalczów, Gacz, Upuszczów, Raczkowo, Sądzimirowice, 1/2 wsi Sobiessąki, wś. pus. Grabow i 21 . os. wsi Błaski. Do tej pozycji dóbr Kalinowskich, d. Kamion w p. kalis. I wolny wyręb w Strzałkowie na wybud. Dworu w kamieniu i pilne potrzeby kmieci; [...] r. 1530 (f. 449);

- dokument z 1558 r. wspomina o podziale majątku między synów Wacława Zaremby, braci - Andrzeja, Jana, Wacława i Jerzego, gdzie młodsi „Wacław i Jerzy dostają: Kalinową, Sędzimirowice, Gawrzyjałów, Boczków, Domaniów, Upuszczów, Towalczew, Kawieczyny, Gać, Kawieczynko, Grabów w p. sieradzkim (p. 1329)” (Teki Dworzaczka... 2004: poz. 2260);

- dokument z roku 1616 zawiera następującą informację (Teki Dworzaczka... 2004: poz 4214):

Marcin z Kalinowy Zaremba starosta grabowski, wś. dzidz. Lubicz w p. poz., którą kupił od Stanisława Przecławskiego stolnika poznań., temuż odsprzedaje (f. 25IV) a stolnik wsie Kalinowa, Radzkowo, Kawieczyn i in. w p. sieradz. Kupione od starosty, ście oddaje (f. 253); 
- w latach 1619-1640 Łubieńscy kupili Kalinową od Zarembów (Białłowicz-Krygierowa 1962: 8-9);

- Kalinowa wraz z arcis została darowana Wojciechowi Janowi Łubieńskiemu (ur. około 1610, zm. 1652/1653), synowi Jana Łubieńskiego i Zofii Wyleżyńskiej, stolnikowi sieradzkiemu (1643), chorążemu sieradzkiemu (1646), kasztelanowi sieradzkiemu (1648/1649) i staroście przedeckiemu. Wojciech jest wzmiankowany jako dziedzic Kalinowej w roku 1638 (Teki Dworzaczka... 2004). Z okresem panowania Łubieńskich wiązane są znaczne prace budowlane;

- Kalinowa przechodzi na własność rodziny Siemiątkowskich ${ }^{1}$, a następnie Szrubarskich;

- w 1858 r. właścicielem Kalinowej został Hipolit Golcz, a następnie rodzina Murzynowskich;

- 1916 r. - przebudowa dworu według projektu biura Horn i Rupiewicz;

- 1945 r. - majątek przechodzi na własność skarbu państwa;

- 2011 r. - zakup dworu i parku przez firmę Agrosad;

Lokalizację wykopów archeologicznych prezentuje poniższy plan (ryc. 1). Naniesiono je na zapożyczony z opracowania architektonicznego rzut parteru z zaznaczonymi dodatkowo punktami węzłowymi (Modrzejewska-Mrozowska i in. 2011: 131).

Lokalizacja wykopu 1 była ściśle związana z wynikami prac architektonicznych, w trakcie których odkryto partie ścian wykonanych ze sztrycharskiej cegły ceramicznej pełnej tzw. palcówki łączonej zaprawą wapienną, posiadających ładnie opracowaną spoinę. Wskazywało to na fakt, iż mury te z założenia nie miały być tynkowane, co jest charakterystyczne dla architektury gotyckiej. Ponadto, badaczka obiektu Z. Białłowicz-Krygierowa wspominała o istnieniu, w omawianym miejscu, przerwanego fundamentu o przebiegu w kierunku północnym.

Początkowo eksplorację rozpoczęto w ramach wykopu o wymiarach 2 x 3 m. Prace $w$ tej części jednostki badawczej prowadzone były w obrębie olbrzymich wkopów związanych przede wszystkim z wykonaniem bitumicznej opaski

\footnotetext{
${ }^{1}$ Kalinowa bez wątpienia związana była z Antonim Siemiątkowskim h. Jastrzębiec (1758-1826), pisarzem ziemskim sieradzkim, radcą woj. kaliskiego i posłem, dziedzicem Wojsławic, Męckiej Woli, Tymienic, Stradzewa, Kowali, Zborowskich, Zagórek, Korczowa, Kaliszan, Golkowa i Biskupic. W Kalinowej urodził się w roku 1789 jego syn - Ignacy Józef Wenaty, zmarła w roku 1821 córka Ignacego - Izabela Donata Celestyna (Teki Dworzaczka... 2004; Nejman 2009: 16-18).

${ }^{2}$ Piotr Paweł Szrubarski był rejentem, Regentem Kancelarii Powiatu Kaliskiego, Komornikiem Trybunału Kaliskiego i Komornikiem Trybunału Cywilnego Województwa Kaliskiego (APK 1835: karta 356-357; Powszechny Dziennik... 1831).
} 


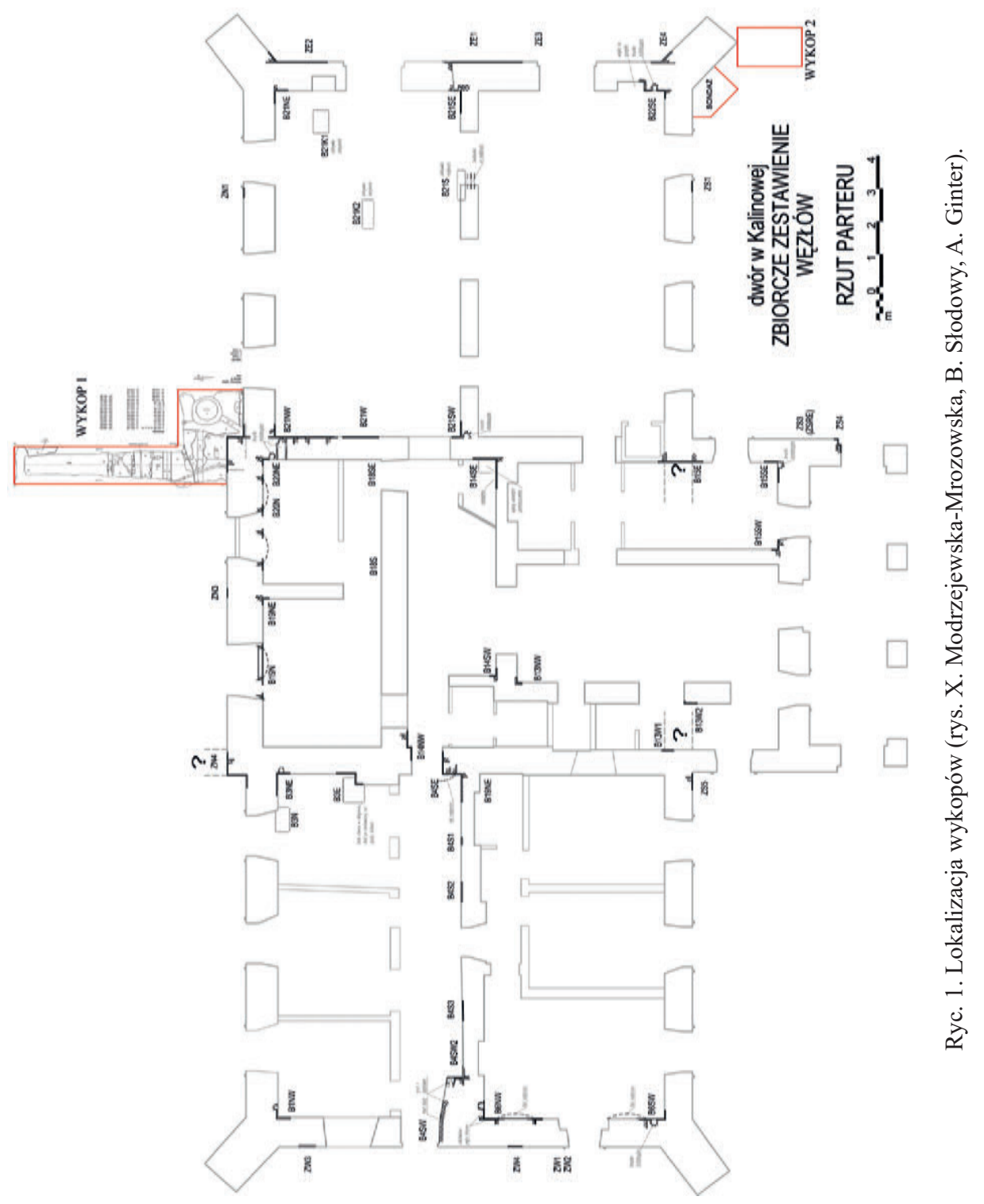


przeciwwilgociowej fundamentów (warstwy 2,10). Ponadto przez omawiany wykop przebiegały dwie rury wodociągowe, dwie rury kanalizacyjne oraz instalacja odgromowa. We wschodniej części znajdowała się również cementowa studnia kanalizacji deszczowej, podłączona bezpośrednio do rynny (wkop pod nią oznaczono $\mathrm{nr} 7$ ). W efekcie tychże prac instalatorskich nawarstwienia historyczne zostały całkowicie przemieszane, a tym samym dwór został odcięty od pozostałej części stratygrafii średniowiecznej i nowożytnej, co uniemożliwiło bezpośrednią korelację murów północnej ściany dworu z odkrytymi w wykopie poziomami kulturowymi.

W stopniu zadowalającym zachował się jednak wspomniany przez Z. Białłowicz-Krygierową relikt fundamentu odsłonięty na poziomie 151,86 m n.p.m. i oznaczony nr 1 (ryc. 1, 2). Wykonano go stosunkowo starannie w technice opus emplectum z kamieni oraz cegieł (tzw. palcówek) łączonych zaprawą wapienną. W dwóch miejscach został on przerwany przez wykopy pod instalację kanalizacyjną i wodociągową o przebiegu wschód - zachód. Posadowiono go w warstwie gliny calcowej, na poziomie 150,65 m n.p.m. Konstrukcyjnie zbliżony był on do fundamentu kamiennego stanowiącego wsparcie dla północnej ściany dworu, przy czym analiza porównawcza nie była możliwa z uwagi na wspomniany powyżej fakt pokrycia fundamentu warstwą izolacji. Również narożnik łączący obydwa te fundamenty nie był dostępny do analizy. Fundament północnej ściany dworu posadowiono na poziomie 150,84 m n.p.m., a więc nieco wyżej niż fundamenty odkryte w wykopie 1.

W związku z zaistniałą sytuacją podjęto decyzję o powiększeniu omawianej jednostki badawczej w kierunku północnym. Celem tego działania było nie tylko uchwycenie kontynuacji reliktu muru nr 1 ale też, co ważniejsze, próba dotarcia do nienaruszonych przez współczesne procesy instalatorskie nawarstwień historycznych.

W efekcie tego, na poziomie 151,58 m n.p.m. zanotowano nie tylko kontynuację muru nr 1, ale także relikt północnej ściany budynku (oznaczony $\mathrm{nr}$ 2) posadowiony na dwóch różnych poziomach: 150,52 m n.p.m. w części północnej i 151,7 m n.p.m. w części południowej (ryc. 2, 4). Ława fundamentu nr 2 miała szerokość $140 \mathrm{~cm}$ w dolnej partii i około $115 \mathrm{~cm}$ w górnej, przy czym wymiar ten otrzymano poprzez odjęcie od $140 \mathrm{~cm}$ pomnożonej przez dwa szerokości odsadzki odkrytej wzdłuż północnego lica. Obliczenia te były konieczne w uwagi na fakt, iż lico muru od strony południowej na badanym odcinku zostało zniszczone przez wkop pod instalację wodociągową do poziomu 151,19 m n.p.m. Dolną część fundamentu wykonano we wkopie ścisłym z kamieni i średniego gruzu ceglanego, układanych warstwami obficie przelewanymi zaprawą wapienną. Na tak przygotowanej ławie wymurowano z kamieni i cegieł w bardzo niestaranny sposób kolejny poziom fundamentu. Niestety, do dnia dzisiejszego nie zachował się nawet fragment ściany, która pierwotnie stała na omawianym 


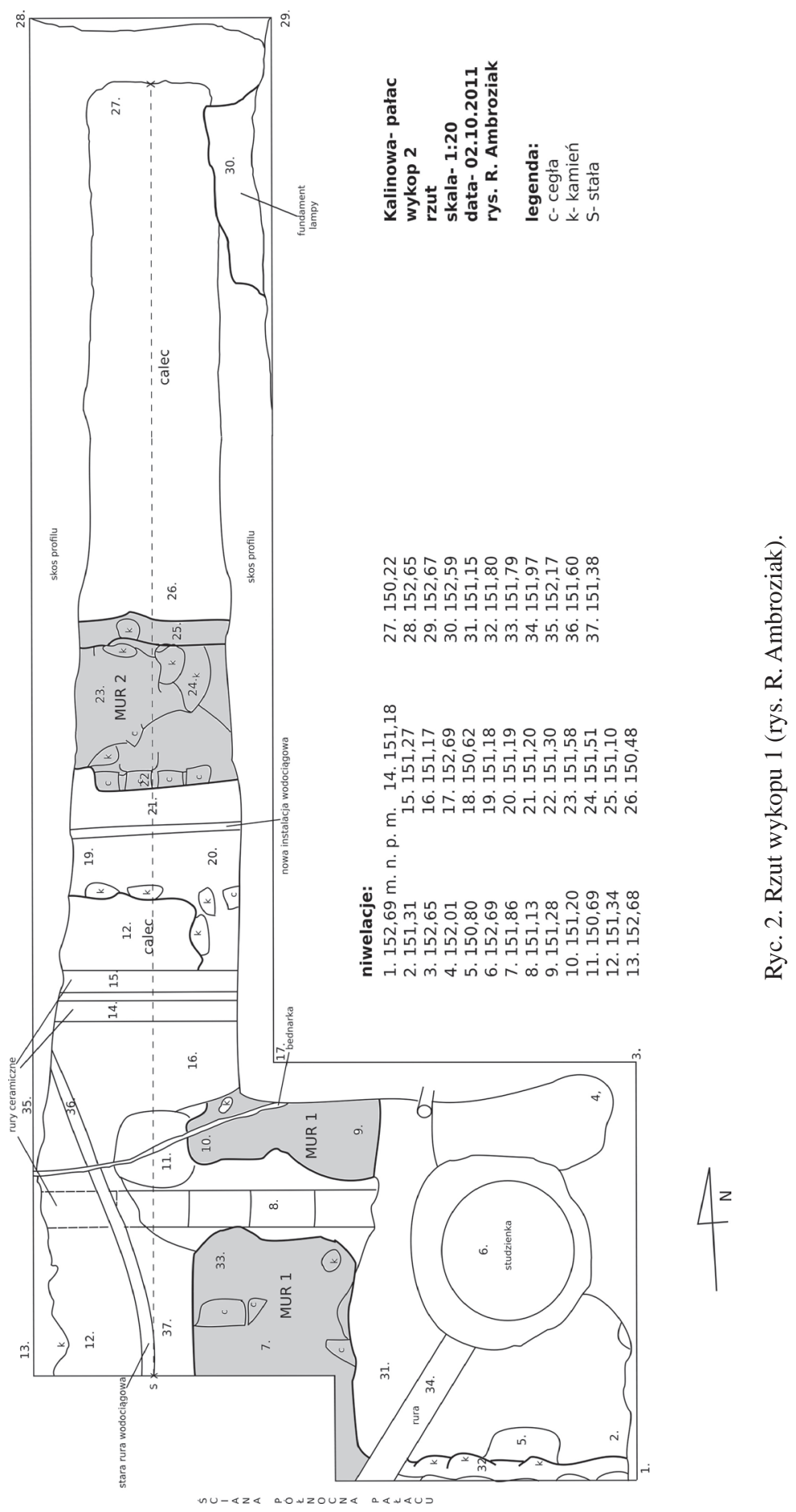



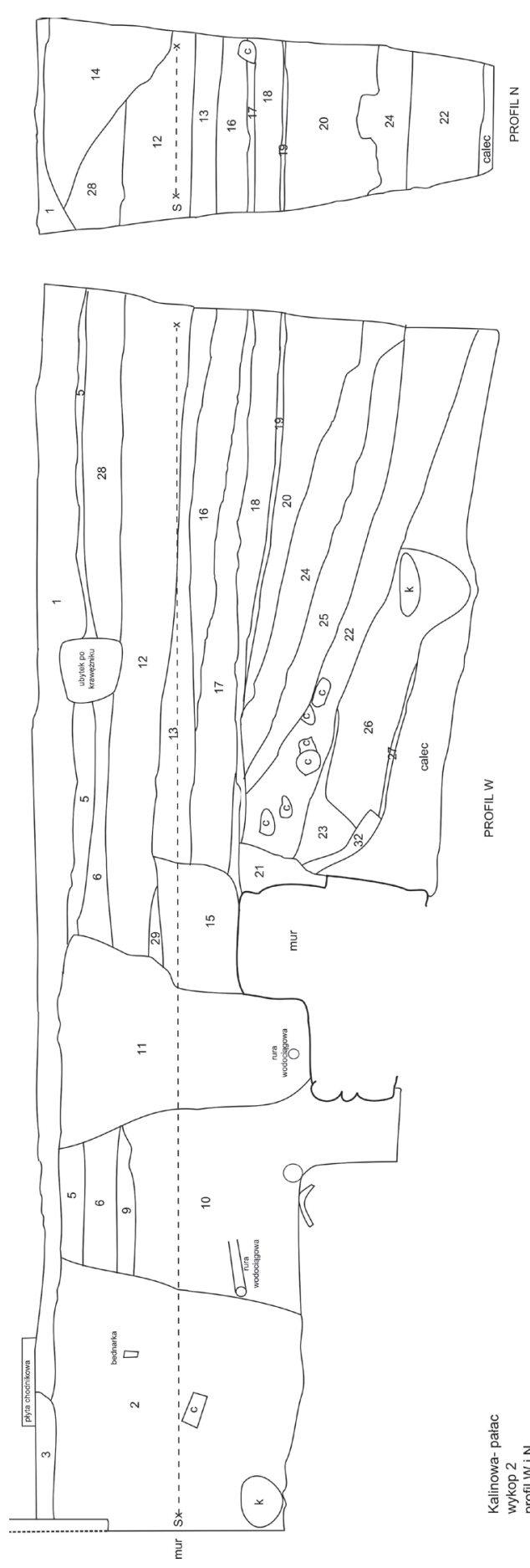

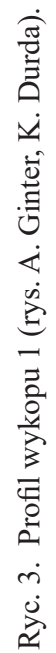

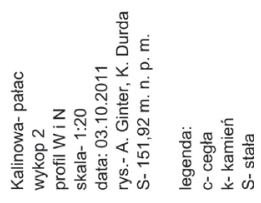


fundamencie, bowiem została ona starannie rozebrana, o czym świadczy wkop oznaczony nr 15. Poziom użytkowy budynku w tej fazie znajdował się najprawdopodobniej nieco ponad poziomem 151,58 m n.p.m. Fundamenty nr 1 i 2 były ze sobą przewiązane.

Analizę stratygrafii nawarstwień ziemnych (ryc. 3, 5) należy rozpocząć od stwierdzenia, iż pierwotnie w miejscu prowadzonych przez nas prac teren był ukształtowany w sposób odmienny od dzisiejszego. Układ gliny calcowej oraz zalegających na niej warstw wskazuje, iż przed pojawieniem się osadnictwa w miejscu posadowienia fundamentu nr 2 i na północ od niego znajdował się stok zbocza o nachyleniu około $30^{\circ}$ (na 3 m spadek wyniósł około $90 \mathrm{~cm}$ ). Stok ten był stopniowo niwelowany poprzez nadsypywanie go kolejnymi poziomami gruzu oraz piasku z próchnicą.

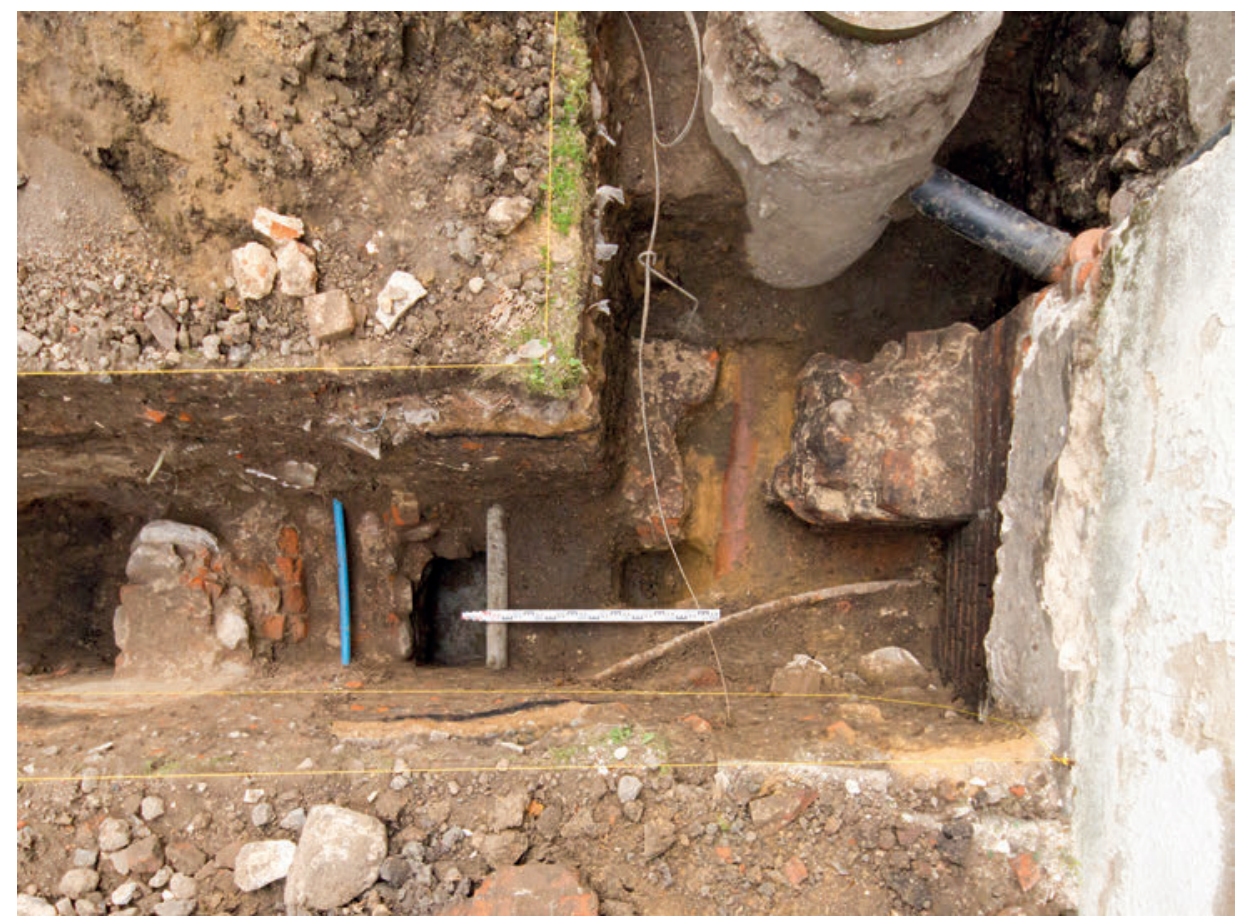

Ryc. 4. Konstrukcje murowane odkryte w wykopie 1 (fot. A. Ginter).

Bez wątpienia najciekawszą z warstw niwelacyjnych była ta oznaczona nr 22. W jej obrębie znaleziono znaczną ilość cegieł tzw. palcówek o wymiarach zbliżonych do cegieł, z których wybudowany został stojący nieopodal kościół. Ponadto pozyskano z niej denar koronny Władysława Jagiełły oraz datowane na pierwszą ćwierć wieku XVI kafle o wyraźnych cechach gotyckich (m.in. maswerkowy). 
Warstwa ta przesycona była przepaloną gliną oraz drobnymi węgielkami, przy czym nie natrafiono w niej na ślady zaprawy wapiennej. Część cegieł nosiła także ślady działania bardzo wysokiej temperatury. Obserwacje te wskazują na fakt, iż są to pozostałości po zniszczonym wskutek pożaru i zepchniętym wzdłuż zbocza obiekcie, w obrębie którego stały piece o wyraźnych cechach gotyckich. Datowanie kafli oraz ceramiki na początek XVI w. oraz obecność monety z pierwszej połowy wieku XV może wskazywać, iż na przełomie późnego średniowiecza i nowożytności na południe od naszego wykopu stał obiekt mieszkalny wykonany z drewna, bądź w konstrukcji szachulcowej. Po pożarze, który miał miejsce w XVI bądź początku XVII w. pozostałości po nim zostały rozplantowane wzdłuż zbocza poszerzając tym samym plateau pod nową budowę. Do warstw niwelacyjnych tej fazy zaliczyć można także jednostki stratygraficzne 20, 24 i 25. Z obrębu tej pierwszej pozyskany został srebrny półgrosz Aleksandra Jagiellończyka datowany na lata 1501-1506.

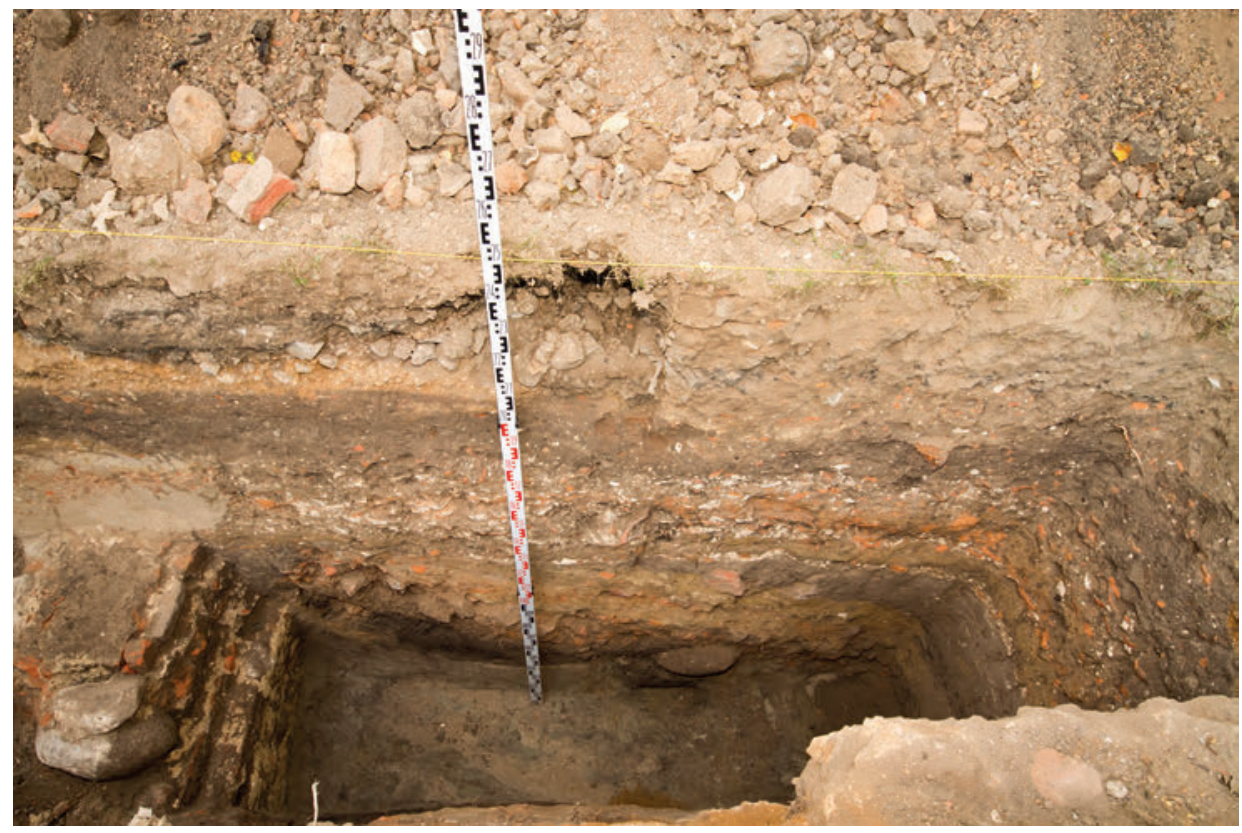

Ryc. 5. Zachodni profil wykopu 1 na północ od muru 2 (fot. A. Ginter).

Pod koniec wieku XVI lub, co bardziej prawdopodobne, w wieku XVII wzniesiono budynek murowany, którego relikty manifestowane są w wykopie 1 w postaci fundamentów nr 1 i 2 . Wkop pod budowę nowego założenia (nr 21) wyraźnie przeciął nawarstwienia o metryce szesnastowiecznej. Przywołując sporządzoną na potrzeby niniejszego opracowania kwerendę źródłową, wydaje się iż budowę tę można powiązać z zakupem Kalinowej przez Łubieńskich herbu Pomian w latach 
dwudziestych lub trzydziestych XVII w. Z użytkowaniem obiektu tej fazy związane są warstwy o $\mathrm{nr}$ 18, 30 i 31. Dwór funkcjonował na pewno do początku wieku XVIII, przy czym opis pochodzący z 1719 r. wskazuje, iż w okresie tym znajdował się on w bardzo złym stanie technicznym. W XVIII w. nastąpiła najprawdopodobniej gruntowna przebudowa obiektu. Częściowo rozebrano osiemnastowieczne mury, w tym także te znalezione w obrębie wykopu 1 (o czym świadczy wkop rozbiórkowy nr 15). Rozebrano też kilka wykonanych w pierwszej połowie XVII w. pieców, których liczne pozostałości znaleziono w warstwie 16.

Następnie wybudowano nowy dwór, który istnieje w zmienionej nieco formie do dnia dzisiejszego.

Badania w obrębie wykopu 2 miały dwa podstawowe cele. Pierwszym, jak już wyżej wspomniano, była próba uchwycenia ewentualnej kontynuacji ściany wschodniej dworu w kierunku południowym. Drugą bardzo ważną kwestią było rozpoznanie nawarstwień ziemnych po tej stronie dworu.

$\mathrm{W}$ efekcie przeprowadzonej eksploracji ustalono, iż w obrębie wykopu nie ma śladów po żadnych konstrukcjach murowanych. Natrafiono natomiast na szereg instalacji, które w znacznym stopniu zniszczyły oryginalne nawarstwienia ziemne (ryc. 6). Na szczęście w południowej części wykopu udało się uchwycić kilka nienaruszonych poziomów historycznych, na podstawie których, przynajmniej częściowo, poczyniono pewne obserwacje stanowiące wstęp do ewentualnych przyszłych prac badawczych.

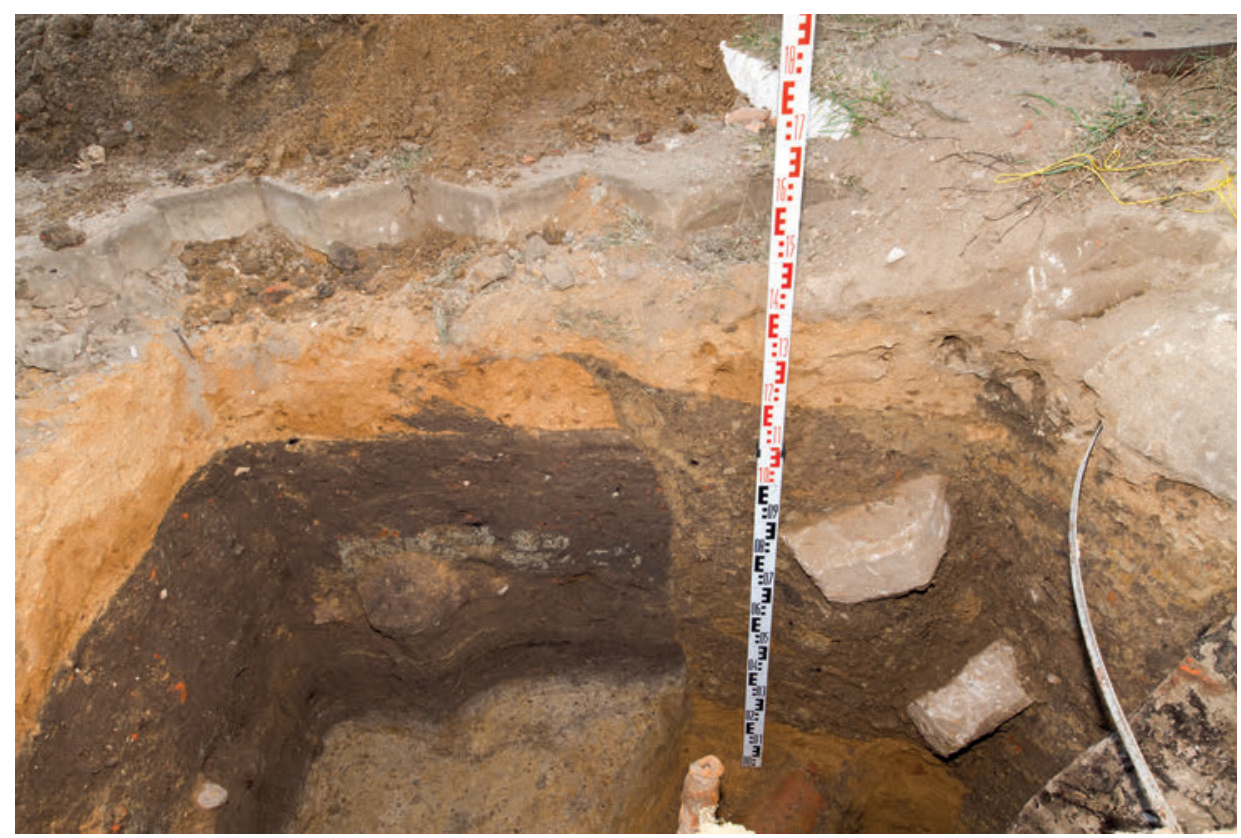

Ryc. 6. Zachodni profil wykopu 2 (fot. A. Ginter). 
Analizę stratygrafii należy zacząć od stwierdzenia, iż warstwy o największej miąższości związane były z akcjami instalatorskimi i niwelacyjnymi przełomu XX i XXI w. Warstwę nr 1 stanowiła trylinka ułożona na grubej warstwie piasku (nr 2). Pod nimi znajdowały się rozległe wkopy instalatorskie nr 3, 4 i 9 o silnie przemieszanym wypełnisku, w obrębie których zalegały całe i połamane trylinki. Współczesną metrykę posiadały ponadto warstwy nr 4, 7 i 12 stanowiące podsypki pod rury i przewody.

Pierwszą warstwą historyczną była warstwa gliny (nr 10) położona na warstwie bruku (nr 5). Bruk ten zalegał na poziomie niwelacyjnym 151,86 m n.p.m. i związany był najprawdopodobniej z osiemnastowieczną fazą użytkowania dworu. Znajdujące się pod nim stosunkowo grube warstwy próchnicy z piaskiem i śladami spalenizny wyznaczają najstarszy horyzont łączony z osadnictwem datowanym na XV i XVI w. Ślady spalenizny mogą wskazywać na gwałtowną destrukcję obiektu, którego pozostałości odkryto w warstwie 22 wykopu 1. Wszystkie warstwy zalegały na szarym gliniastym calcu z domieszką żółtego piasku.

\section{Analiza ZabYTKów}

W trakcie prac badawczych pozyskano i zainwentaryzowano łącznie aż 969 zabytków ruchomych. Liczba ta w odniesieniu do niewielkiej powierzchni wykopów wyraźnie wskazuje na fakt, iż badany obszar był świadkiem wielu procesów historycznych o zróżnicowanych charakterze i intensywności.

Zdecydowana większość zabytków pozyskana została z wykopu 1 (wykres 1). Wynika to nie tylko z faktu, iż posiadał on znaczniejsze rozmiary, ale przede wszystkim z tego, że w jego obrębie uchwycono na dużej powierzchni nienaruszony układ nawarstwień historycznych. W wykopie 2 oryginalne, nieprzemieszane wskutek prac instalatorskich poziomy kulturowe stanowiły niewielki procent całości.

Najliczniejsza grupa zabytków pozyskana została z warstwy nr 16 wykopu 1 (aż 512 sztuk). Poziom ten uformowany został, jak już wyżej wspomniano, w trakcie znacznej akcji budowlanej bądź remontowej, w ramach której wymieniano także piece dworskie. W efekcie do umocnienia stoku wyspy użyto fragmentów kafli z ich rozbiórki. Warto również zwrócić uwagę na fakt, iż pozostałe warstwy, czy to te uchwycone w wykopie 1 czy 2, wskazują na bardzo zbliżony poziom nasycenia materiałem zabytkowym (od 22 do 34 sztuk). Jedynie warstwy 13 i 27 zawierały większą liczbę, stosunkowo silnie zróżnicowanego materiału zabytkowego.

Fragmenty naczyń ceramicznych są najliczniej reprezentowaną grupą zabytków na wszystkich późnośredniowiecznych i nowożytnych stanowiskach archeologicznych. Wyjątkowo, w przypadku dworu w Kalinowej, liczba znale- 


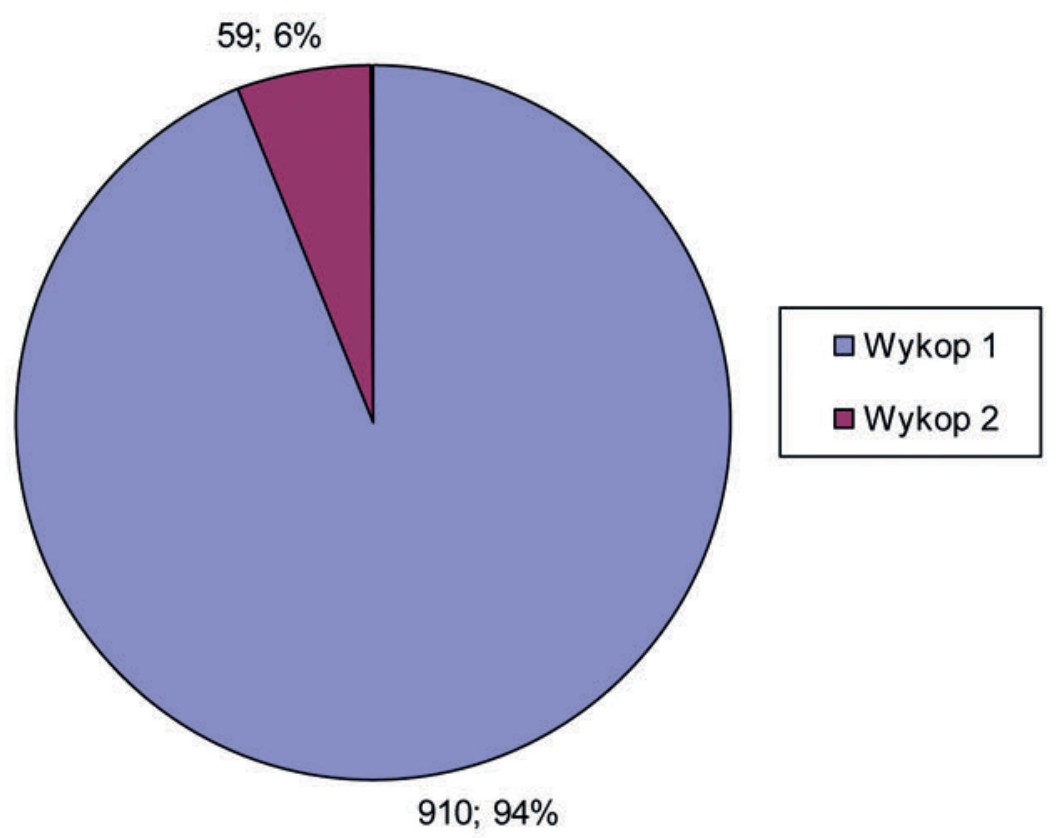

Wykres 1. Ilość i udział procentowy zabytków w poszczególnych wykopach (oprac. A. Ginter).

zionych ułamków ceramiki naczyniowej (wykresy 2,3) była niższa od kafli piecowych $(43,2 \%)$ i wynosiła 411 sztuk, co stanowi niecałe $42,7 \%$ całego zbioru. Zdecydowana większość z nich posiada metrykę nowożytną, dlatego opracowano je w oparciu o podział wprowadzony do literatury przedmiotu przez Leszka Kajzera (1986: 199-225; 1991: 467-484). Jeden fragment brzuśca został z tego podziału wyłączony, gdyż zaklasyfikowano go chronologicznie do okresu pradziejów.

Pozostałe grupy zabytków nie przekraczają 6\% całego zbioru. Wśród przedmiotów metalowych zdecydowanie dominują różnej wielkości gwoździe, których znaleziono 41 sztuk.

\section{Ceramika naczyniowa}

Ceramika typu A, reprezentowana zaledwie przez 11 fragmentów, nawiązuje morfologią, technologią i ornamentyką do wczesnośredniowiecznych tradycji garncarskich. Wypalana była w atmosferze utleniającej uzyskując kolor brunatny lub kremowy, a masa ceramiczna zawiera grubo i średnioziarniste domieszki schudzające. Wypał odbywał się w nie w pełni kontrolowanej atmosferze, dlatego ich przełamy w większości przypadków były wielobarwne. Niewielka ilość tego typu naczyń na badanym stanowisku związana jest bez- 


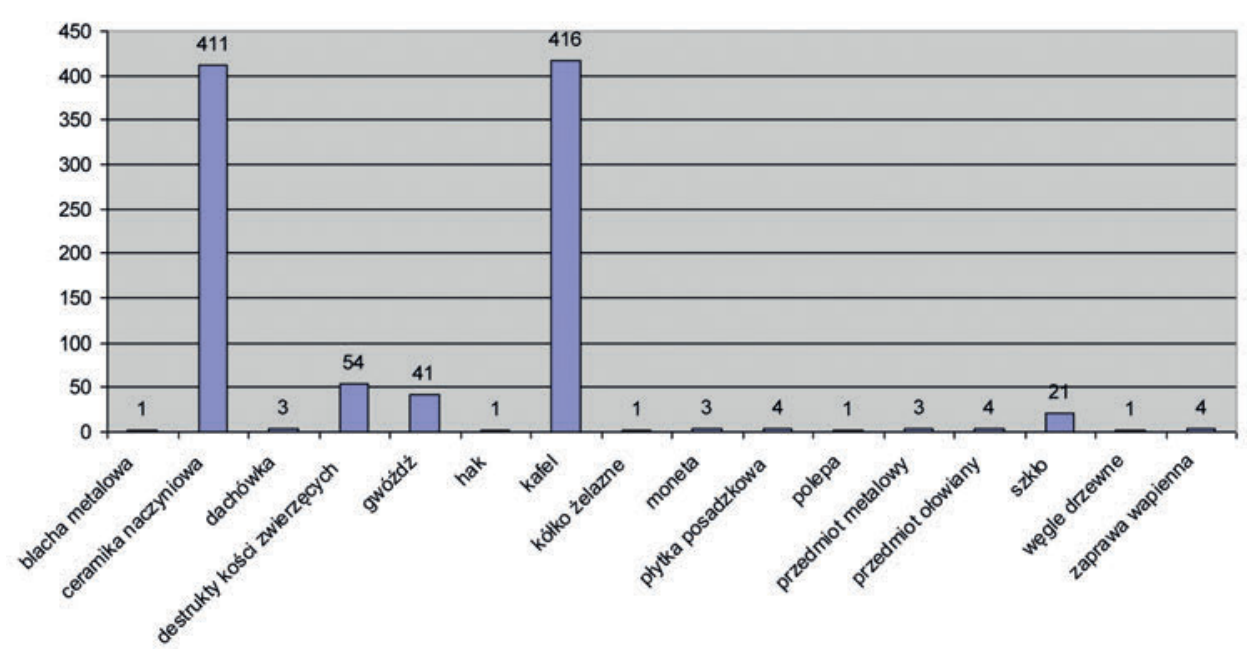

Wykres 2. Udział zabytków poszczególnych rodzajów (oprac. A. Ginter).

pośrednio z chronologią odkrytych warstw. Znalezione zostały przede wszystkim w obrębie najstarszych poziomów osadniczych wiązanych z okresem późnego średniowiecza i wczesnonowożytnym. Zabytki tej grupy zdobione były głównie za pomocą poziomych rytych linii bądź karbowania powierzchni. Niewielkie fragmenty nie pozwalają na jednoznaczne ustalenie form $\mathrm{z}$ jakich pochodziły.

Ceramika typu B, stanowiąca aż 36\% całości omawianego zbioru, to tzw. ceramika kuchenna. Do wytworzenia pozyskanych w trakcie badań naczyń tej grupy, użyto masy ceramicznej schudzanej średnio lub drobnoziarnistą domieszką, powodującą niewielką chropowatość ścianek. Wypalano je w atmosferze redukcyjnej, a sam proces był dostatecznie dobrze kontrolowany, gdyż przełamy naczyń w większości przypadków posiadały jednolitą czarną bądź szarą barwę.

Ceramika tego typu, znaleziona w Kalinowej, zdobiona była najczęściej poprzez naniesienie na górną część brzuśca poziomych dookolnych rowków. Niejednokrotnie też zabytki w omawianym zbiorze były karbowane. Sporadycznie stosowano wyświecanie powierzchni zarezerwowane zazwyczaj dla naczyń należących do typu C. Wśród znalezionych artefaktów dominowały garnki i dzbany o mocno zróżnicowanej wielkości.

Naczynia grupy $\mathbf{C}$ (tzw. ceramika stołowa), wykonane z glin żelazistych lub kaolinitowych z bardzo drobną domieszką schudzającą wypalane były w stabilnej, redukcyjnej atmosferze. Efektem tych działań były cienkościenne formy, z ciemnoszarym lub czarnym kolorem czerepu i jednobarwnym przełamem. Ponieważ wykonanie tego typu ceramiki wymagało dużych umiejętności 


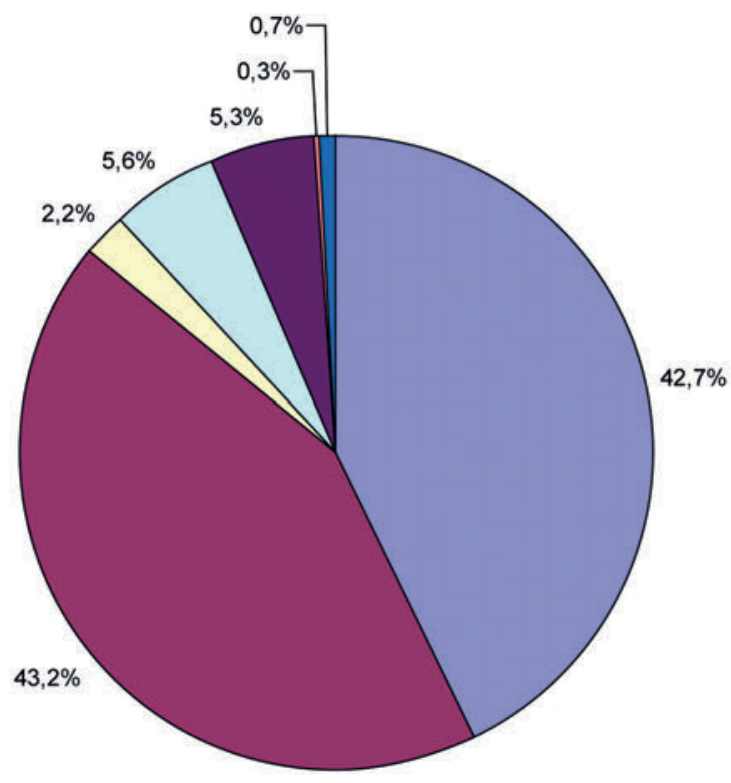

\begin{tabular}{|l|}
\hline ceramika naczyniowa \\
$\square$ kafel \\
$\square$ szkło \\
$\square$ destrukty kości zwierzęcych \\
$\square$ przedmioty metalowe \\
$\square$ monety \\
$\square$ ceramika budowlana \\
\hline
\end{tabular}

Wykres 3. Procentowy udział poszczególnych grup zabytków w całości zbioru (oprac. A. Ginter).

oraz zajmowało znacznie więcej czasu niż wylepienie utensyliów kuchennych, stanowi ona tylko niewielki procent całego zbioru artefaktów ceramicznych (łącznie znaleziono 32 zabytki tego typu).

Brzuśce zdobiono przede wszystkim za pomocą wyświecanych linii, ale także stempelkiem, co nadawało im reprezentacyjny wygląd. Kalinowska zastawa stołowa składała się w głównej mierze z małych i średniej wielkości garnków, mis oraz kubków.

Wytwórczość ceramiki typu C rozkwita w okresie późnego średniowiecza i wczesnonowożytnym, a w nowożytności jej funkcję przejmują naczynia wypalane w atmosferze utleniającej.

W okresie nowożytnym upowszechniła się zupełnie inna, od wyżej omówionych, technologia, jaką jest wypał ceramiki w atmosferze silnie utleniającej. W zależności od rodzaju użytej gliny, czy to żelazistej, czy też kaolinitowej uzyskiwano wyroby o kolorze odpowiednio czerwonym lub białym. Im przyporządkował L. Kajzer grupę D i podzielił ją na Dc - czerepy czerwone wykonane z glin żelazistych, Db - białe uformowane z glin kaolinitowych.

Naczynia wykonane z glin kaolinitowych stanowią znaczny procent omawianego zbioru, gdyż pozyskano łącznie 85 fragmentów tego typu. Ich jakość jest stosunkowo wysoka. Czerepy wykonano starannie, przy czym niekiedy zastosowano znaczną ilość grubej domieszki schudzającej, co wyraźnie wpłynęło na walory wizualne naczyń. Brzuśce zdobiono za pomocą dookolnych rowków 
oraz karbowania powierzchni. Znalezione fragmenty pochodziły przede wszystkim z garnków, kubków i dzbanków.

Znacznie mniejszy zbiór zabytków stanowiły pozostałości naczyń typu Dc. Łącznie pozyskano zaledwie 47 artefaktów tej grupy (11\% całości). Były to przede wszystkim niewielkie, mało charakterystyczne fragmenty garnków ornamentowane niekiedy analogicznie do zabytków typu $\mathrm{Db}$.

Trzecią, pod względem liczności, grupą były ułamki ceramiki polewanej (typ E). Stanowiły one $20 \%$ całego zbioru. Na grupę tę składały się przede wszystkim cienkościenne, dobrze wypalone naczynia polewane od wewnątrz. W omawianym zbiorze dominowały polewy zielone, brązowe, żółte oraz rzadziej kremowe, białe i oliwkowe. Stanowiły one fragmenty czarek, mis, kubków i garnuszków zdobionych sporadycznie motywem kratki, ornamentem roślinnym bądź geometrycznym.

Ostatnią omawianą grupę $\mathbf{F}$ reprezentują zaledwie 3 zabytki. Do niej L. Kajzer zaliczył wszelkie rodzaje ceramiki, które nie przynależały do żadnej z powyższych grup. Między innymi są to naczynia malowane i angobowane, ale także kamionkowe, fajansowe, majolikowe, półmajolikowe czy porcelanowe. W omawianym zbiorze znalazły się dwa fragmenty niewielkich malowanych na biało naczyń oraz jeden ułamek naczynia fajansowego z dekoracją roślinną.

\section{Kafle}

Zdecydowanie najciekawszym zbiorem zabytków pozyskanych w trakcie badań w Kalinowej był zestaw kafli piecowych, które stanowiły ponad $43 \%$ całości. Wśród nich znaczną przewagę miały fragmenty kafli płytowych, których odkryto aż 410 sztuk. Zaledwie 6 artefaktów zaliczono do grupy kafli garnczkowych.

W zbiorze kafli płytowych przeważały fragmenty komór kafli wykonane, podobnie jak lica, z glin żelazistych. Na kilku z nich stwierdzono ślady polewy oraz obecność otworów montażowych.

Dużo ciekawsze pod kątem analizy stylistycznej i chronologicznej są płyty, których zainwentaryzowano łącznie 138 sztuk.

Analizując poszczególne grupy zabytków wyróżniono dwie główne fazy wymiany pieców dworskich.

Najstarsze zabytki tego typu odkryte zostały w warstwie nr 22. Były to polewane na zielono kafle zwieńczające piec o bardzo ciekawej stylistyce (ryc. 7).

Pierwszy z nich, wzorowany był na gotyckich ostrołukowych arkadach zwieńczonych trójkątnymi szczytami (tzw. wimpergami) z czworolistną dekoracją maswerkową. Kafle tego typu wytwarzane były w pierwszej połowie XVI w. Formy zbliżone do zabytku z Kalinowej znamy z zamku w Czersku, Inowłodzu oraz dworu w Spytkowicach (Dąbrowska 1987: 21, 85, 114). 

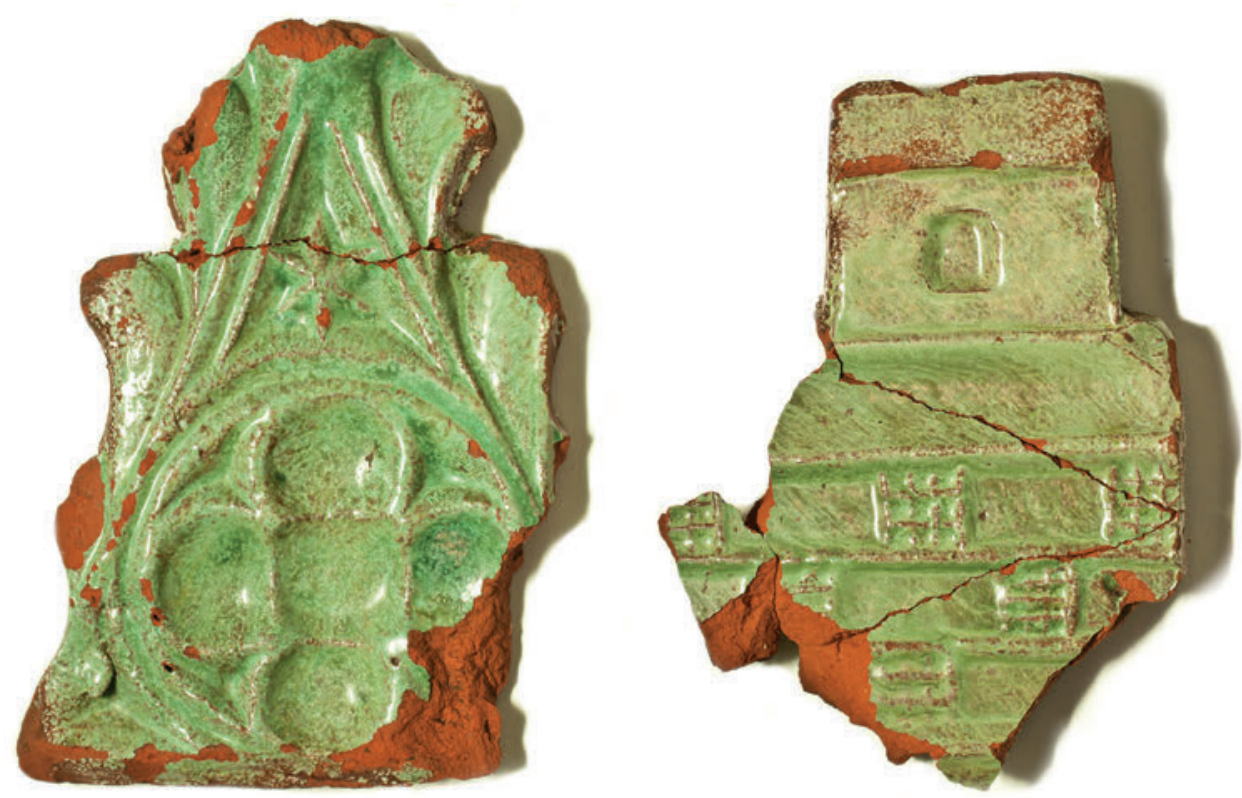

Ryc. 7. Kafle z pierwszej ćwierci XVI wieku znalezione w wykopie 1 (fot. A. Ginter).

Drugi z kafli, nie mniej ciekawy, również został pokryty zieloną polewą ołowiową. Uformowany został na kształt krenelażu ze strzelnicami, pod którym symbolicznie naniesione zostały linie gzymsów i okien. Zbliżone do niego zabytki (datowane na pierwszą ćwierć XVI w.) odkryte zostały w trakcie badań dworu w Spytkowicach oraz na zamku w Inowłodzu (Dąbrowska 1987: 54, 87). Bardzo podobny stylistycznie egzemplarz kafla fryzowego datowany na późne średniowiecze znaleziono także w Gnieźnie (stan. 22) (Janiak 2007: 22).

Przytoczone analogie wyraźnie wskazują na fakt, iż mamy do czynienia z zabytkami, które związane są z okresem późnego średniowiecza, a okres ich produkcji przypada na pierwszą połowę (bądź nawet pierwszą ćwierć) wieku XVI.

Kolejny, bardzo ciekawy i znacznie większy od poprzedniego, zbiór kafli pozyskany został z warstwy nr 16 wykopu 1 . Łącznie znaleziono w niej 244 fragmenty kołnierzy i aż 120 fragmentów płyt.

Zdecydowanie najciekawszym artefaktem był niemalże w całości zrekonstruowany kafel z groteskowo przedstawionymi delfinami ujętymi w motywy roślinne i geometryczne (ryc. 8). Obecnie widać na nim silnie zerodowane szkliwo w kolorze brązowym i zielonym. Ma on kształt kwadratu o wymiarach 19,5 na 19,5 cm i niewielką głębokość wynikającą z faktu, iż zawarty na nim ornament miał charakter kontynuacyjny. Bardzo zbliżone motywem dekoracyjnym kafle, ale o odmiennej kolorystyce, datowane na koniec wieku XVI i początek 


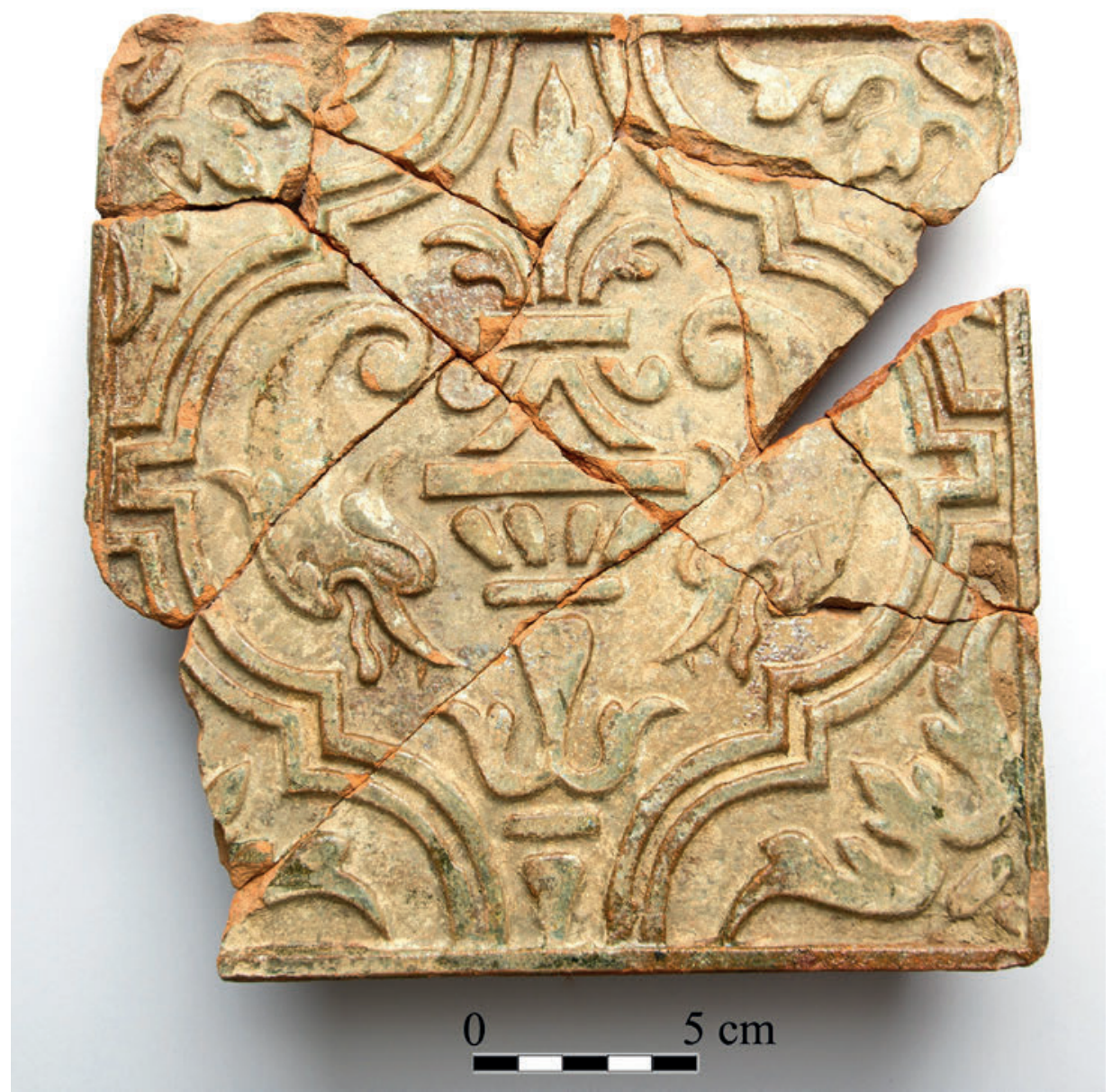

Ryc. 8. Zrekonstruowany kafel przełomu XVI i XVII wieku znaleziony w wykopie 1 (fot. A. Ginter).

wieku XVII odkryte zostały w Malborku i Toruniu (Kilarska, Kilarski 2009: 54) oraz wiązane z pierwszą połową wieku XVII w Poznaniu (Dąbrowska 1987: 134, il. 36).

Kolejnym typem artefaktów pozyskanych w warstwie 16 były zielone kafle z motywami roślinnymi (ryc. 9). Cechowały się wyjątkowo intensywnym kolorem, który nie uległ degradacji oraz znaczną głębokością, sugerującą iż motyw na każdym z nich stanowił zamkniętą całość. W przedstawieniach dominowały elementy roślinne (liście, łodygi) oraz geometryczne. Analogiczne zabytki datowane na pierwszą połowę wieku XVII odkryto w Jarosławiu (Dąbrowska 1987: 134, il. 38). 


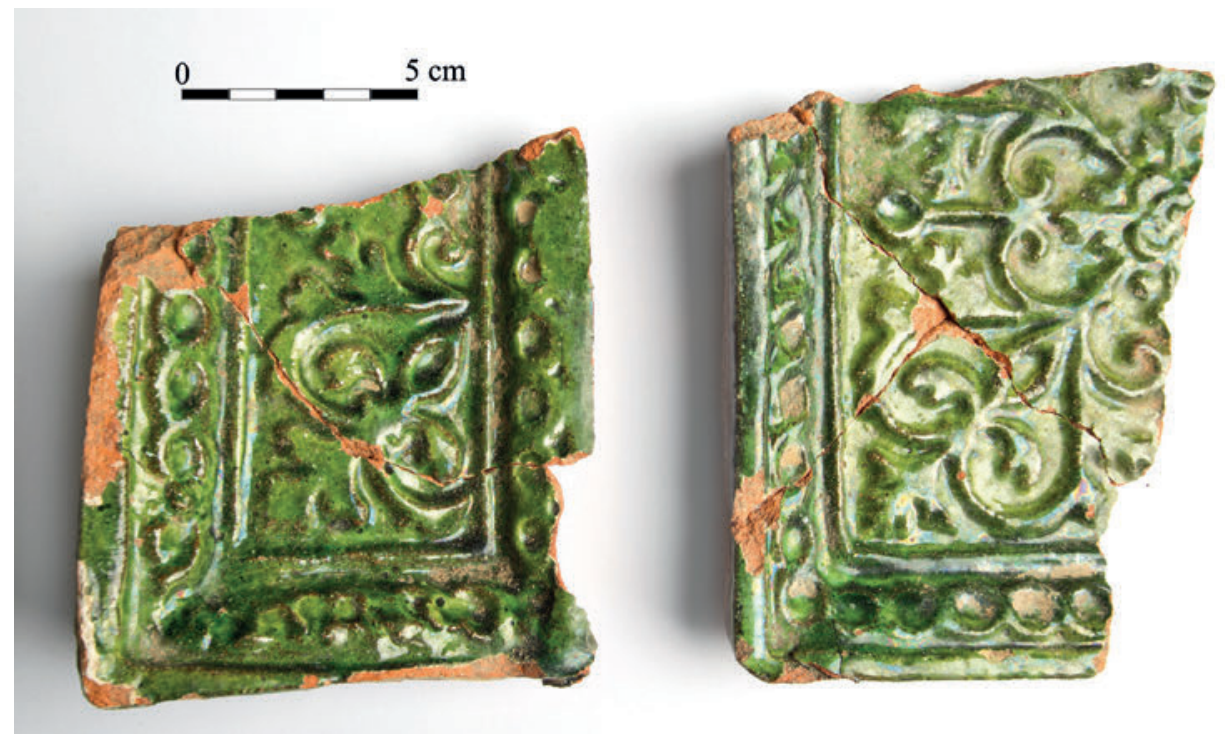

Ryc. 9. Zrekonstruowane kafle z XVII wieku znalezione w wykopie 1 (fot. A. Ginter).

Oprócz kafli środkowych wypełniających udało się częściowo zrekonstruować także pojedyncze kafle gzymsowe o zielonym szkliwie i ornamencie roślinnym.

Ponadto, w trakcie prac znaleziono kilka niewielkich fragmentów polewanych na kolor niebieski, biały, oliwkowy bądź też nieszkliwionych.

Bez wątpienia omawiany zbiór jest zespołem zabytków wyjątkowych. Identyczne do odkrytych w Kalinowej kafle zdobiły pomieszczenia pałaców i kamienic mieszczańskich w dużych i bogatych ośrodkach miejskich w całej Polsce. Obserwacje te wyraźnie wskazują, że mamy do czynienia z obiektem, którego właściciele byli zamożni i znali obowiązujące trendy.

\section{Pozostałe zabytki}

$\mathrm{W}$ tracie prowadzonych prac badawczych udało się pozyskać trzy ciekawe zabytki numizmatyczne (ryc. 10).

Pierwszym z nich jest silnie zniszczony denar Władysława Jagiełły datowany na lata $1389-1434$. Ma on średnicę $11,5 \mathrm{~mm}$ i wykonany został w całości ze srebra.

Kolejną monetą jest zachowany w bardzo dobrym stanie, srebrny półgrosz Aleksandra Jagiellończyka bity w latach 1492-1506. Ma on średnicę 18,6 mm i nieznacznie zdeformowaną powierzchnię.

Ostatnia, najrzadsza z pozyskanych monet, to srebrny szeląg litewski Zygmunta III Wazy wybity najprawdopodobniej w roku 1618. Ma on średnicę 
$18 \mathrm{~mm}$ i wykonany został ze srebra. Niestety moneta została silnie uszkodzona i nie zachowała się w całości do dnia dzisiejszego.
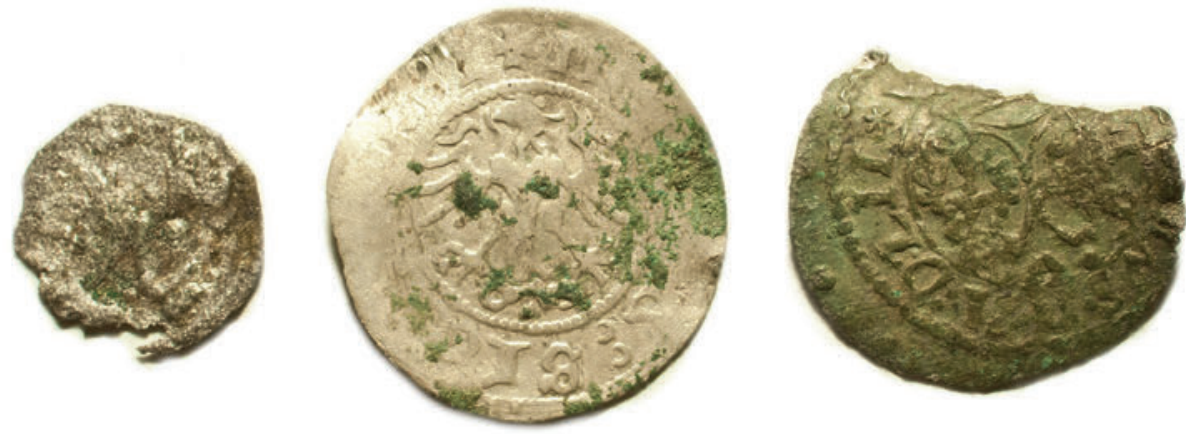

Ryc. 10. Numizmaty znalezione w wykopie 1 (fot. A. Ginter).

Wyjątkowo ciekawym zabytkiem pozyskanym z warstwy 22 jest cynowy przedmiot przypominający kształtem miniaturowy topór (ryc. 11). Zabytek ten ma wymiary: $37 \mathrm{~mm}$ długości i $27 \mathrm{~mm}$ szerokości (w najszerszym miejscu). Uformowany został na kształt topora ze ściętą łukowato brodą, okrągłą osadą z niewielkim obuchem. Z osady zachowała się tylko połowa obwodu. Żeleźce topora (z pominięciem ostrza) zostało bogato ozdobione za pomocą rzędu

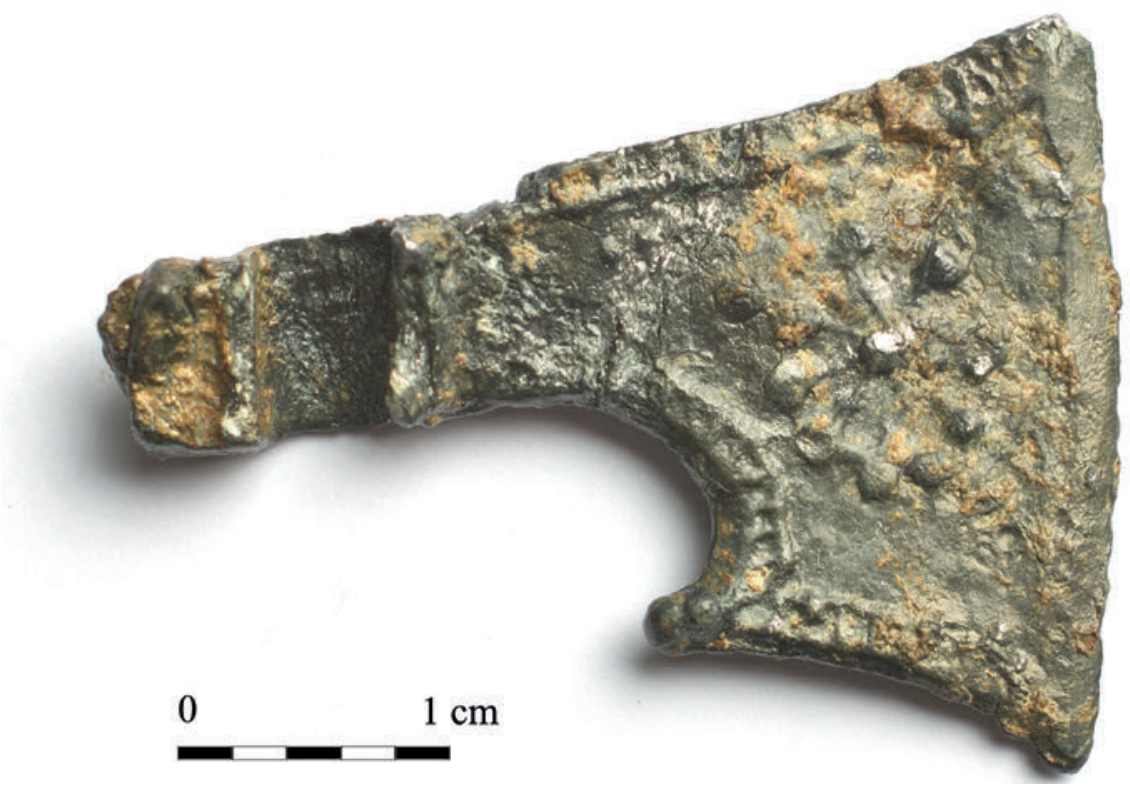

Ryc. 11. Plakietka znaleziona w wykopie 1 (fot. A. Ginter). 
niewielkich prostokątów. Na bocznych powierzchniach umieszczone zostały stylizowane kwiaty. Zabytek ten przypomina swoim kształtem wczesnośredniowieczne miniaturowe toporki typu I (Kucypera i in. 2011), ale w związku z faktem, iż nie natrafiono dotychczas na zabytki, czy też nawarstwienia o takiej metryce należałoby go powiązać raczej z późnośredniowiecznymi plakietkami świeckimi znanymi z obszaru całej Europy. Identyczny zabytek o późnośredniowiecznej metryce znaleziono w Gdańsku (Muzeum Archeologiczne w Gdańsku, Dział Zbiorów Gdańskich, Gdańska Kolekcja Pamiątek Pielgrzymich, numer w kolekcji - 811).

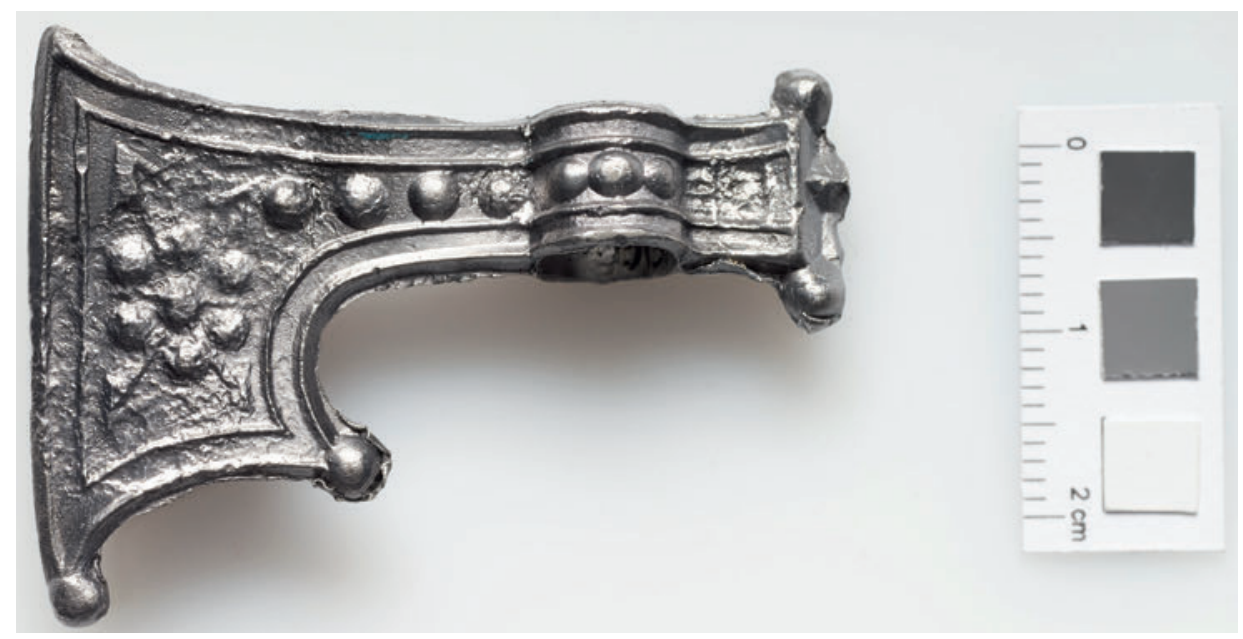

Ryc. 12. Plakietka świecka ze zbiorów Muzeum Archeologicznego w Gdańsku (http://archeoportal.pl/kolekcja/6/zabytek/700, fot. A. Kamrowski).

\section{Podsumowanie}

W efekcie przeprowadzonych prac badawczych osiągnięto zamierzone cele oraz sformułowano kilka nowych pytań badawczych.

Przede wszystkim ustalono, iż z dużą dozą prawdopodobieństwa można przyjąć, że Zarembowie przenieśli swoją siedzibę z wyspy na stały ląd w XV w. Być może działania te powiązać należy z osobą Jana Zaremby, kasztelana sieradzkiego, któremu przypisywana jest także budowa sąsiadującego z dworem murowanego gotyckiego kościoła pw. św. Magdaleny. Zarembowie najprawdopodobniej wybudowali sobie nową rezydencję z drewna lub też w konstrukcji szachulcowej, przy czym nie udało się ustalić jej lokalizacji. Wnętrza zdobiły późnogotyckie, zielone piece kaflowe, a związany z tym okresem zbiór zabytków potwierdza tylko wysoki status rodu Zarembów w średniowiecznej Polsce. Siedziba ta funkcjonowała przez pewien, trudny do określenia czas. W XVI w., 
bądź raczej na początku wieku XVII, z nieustalonych przyczyn obiekt ten spalił się, a pozostałości zostały rozplantowane wzdłuż północnej skarpy prowadzącej do jeziora. Na tak poszerzonym plateau, najprawdopodobniej w latach dwudziestych lub trzydziestych, nowy właściciel Kalinowej, Wojciech Jan Łubieński herbu Pomian, zbudował murowany pałac w typie palazzo in fortezza. Fundamenty pod tę właśnie rezydencję odkryte zostały w wykopie 1 . $\mathrm{Z}$ fazą tą można łączyć także bruki, na które natrafiono w wykopie 2 .

Na początku XVIII w. siedziba Łubieńskich nieco podupadła. Opisy z roku 1719 wskazują nie tylko na konieczność naprawy pieców i okien, ale również wymieniają „,mur poroynowany”. Być może to właśnie zły stan obiektu wymusił jego przebudowę, w trakcie której zmienił się całkowicie plan pałacu. Ściany odkryte w wykopie 1 zostały rozebrane. Wymieniono też mocno już zużyte osiemnastowieczne piece wykonane $\mathrm{z}$ brązowych i zielonych kafli zdobionych motywami roślinnymi i geometrycznymi, które posłużyły do kolejnej niwelacji północnego stoku.

Niezwykła ilość zabytków oraz ich najwyższa jakość w korelacji z ilością odkrytych faz budowlanych i znaczną miąższością nawarstwień wskazują na fakt, iż mamy do czynienia z obiektem wyjątkowym pod każdym względem. Siedziba ta stanowiła najprawdopodobniej już od późnego średniowiecza centrum klucza majątkowego bez względu na to, czy właścicielami byli Zarembowie, czy też Łubieńscy. Wydaje się ponadto, że nie szczędzono pieniędzy na wystój wnętrz, a więc zapewne też i prace budowlane prowadzone były z rozmachem.

W związku z tym badania archeologiczne oprócz kilku odpowiedzi przyniosły także szereg nowych pytań. Nie udało się przede wszystkim ustalić, gdzie znajdowała się późnogotycka rezydencja Zarembów, kiedy dokładnie powstała i jak długo funkcjonowała. Nie wiadomo również, czy Wojciech Jan Łubieński kupując Kalinową wraz z arcis kupił obiekt, którego pozostałości odkryte zostały w warstwie nr 22 wykopu 1, czy inny, wybudowany w XVI w. przez Zarembów po spaleniu się ich pierwszej, poza wyspą, rezydencji. Nie wiadomo też jak wyglądał pierwszy pałac Łubieńskich. Na pewno znacznie różnił się od dzisiejszego założenia, o czym mogą świadczyć fundamenty z wykopu 1 i liczne rozwarstwienia architektonicznie wewnątrz obecnie funkcjonującego obiektu. $\mathrm{Na}$ te pytania odpowiedzi udzielić mogą tylko kolejne, szerzej zakrojone badania archeologiczne.

\author{
Artur Ginter \\ Laboratorium Datowania Termoluminescencyjnego i Spektrometrii \\ Instytut Archeologii \\ Uniwersytet Łódzki \\ ul. Narutowicza 65 \\ 90-131 Łódź \\ e-mail: artur.ginter@uni.lodz.pl
}




\section{Bibliografia}

\section{Źródła}

APK (1835), Archiwum Państwowe w Kaliszu, Księga III Czynności Dobrowolnych przez Piotra Pawła Szrubarskiego Rejenta przyjętych, akt nr 316 z 1835 r., karta nr 356-357, sygnatura 6.

\section{Opracowania}

Białłowicz-Krygierowa Z. (1957), Dwór obronny w Kalinowej, pow. Kalisz. Dokumentacja historyczno-architektoniczna, dokumentacja dostępna w archiwum w Narodowego Instytutu Dziedzictwa, Oddział Terenowy w Poznaniu.

Białłowicz-Krygierowa Z. (1962), Dwór w Kalinowej, „Studia i materiały do dziejów Wielkopolski i Pomorza”, t. VII, z. 1(13), s. 7-19.

Dąbrowska M. (1987), Kafle i piece kaflowe w Polsce do końca XVIII wieku (= Studia i Materiały z Historii Kultury Materialnej t. 58), Zakład Narodowy im. Ossolińskich, Polska Akademia Nauk, Wrocław-Warszawa-Kraków-Gdańsk-Łódź.

Głosek M., Kajzer L., Wójcik A. (1988), Późnośredniowieczna siedziba obronna rodu Zarembów w Kalinowej, gm. Błaszki, woj. sieradzkie $w$ świetle badań weryfikacyjnych przeprowadzonych w 1988 roku, maszynopis dostępny w archiwum Wojewódzkiego Urzędu Ochrony Zabytków w Łodzi - Delegatura w Sieradzu.

Janiak T. (2007), Kafle gotyckie z Wielkopolski, [w:] M. Dąbrowska, H. Karwowska (red.), Średniowieczne i nowożytne kafle. Regionalizmy-Podobieństwa-Różnice, Muzeum Podlaskie w Białymstoku, Białystok, s. 17-35.

Kajzer L. (1986), Opracowanie zbioru ceramiki naczyniowej z ,, wieży Karnkowskiego” zamku w Raciążku, „Kwartalnik Historii Kultury Materialnej”, r. XXXV, nr 2, s. $199-225$.

Kajzer L. (1991), W sprawie waloryzacji masowych zbiorów ceramiki późnośredniowiecznej i nowożytnej, „Kwartalnik Historii Kultury Materialnej”, r. XXXIX, nr 4, s. 467-484.

Kilarska E., Kilarski M. (2009), Kafle z terenu dawnych Prus Królewskich, Muzeum Zamkowe w Malborku, Malbork.

Kucypera P., Pranke P., Wadyl S. (2011), Wczesnośredniowieczne toporki miniaturowe, Wydawnictwo Adam Marszałek, Toruń.

Modrzejewska-Mrozowska X., Słodowy B., Pietrzak J., Ginter A., Ambroziak R., Durda K., Bystroń-Kunat M. (2011), Dwór w Kalinowej. Wyniki badań architektonicznych przeprowadzonych w 2011 roku, maszynopis dostępny w archiwum Wojewódzkiego Urzędu Ochrony Zabytków w Łodzi.

Nejman E. (2009), Rodzina Siemiatkowskich w Sieradzkiem, „Na sieradzkich szlakach”, t. XXIV, nr 2, s. 16-18. 


\section{Źródla internetowe}

http://archeoportal.pl/kolekcja/6/zabytek/700 (dostęp: 12.10.2018).

Powszechny Dziennik... (1831), Powszechny Dziennik Krajowy, Licytacje i sprzedaże publiczne, http://ebuw.uw.edu.pl/dlibra/plain-content?id=36121 (dostęp: 3.09.2018).

Teki Dworzaczka... (2004), Teki Dworzaczka. Materiaty historyczno-genealogiczne do dziejów szlachty wielkopolskiej $X V$-XX wieku, Jerzy Wisłocki (kier. nauk.), Polska Akademia Nauk, Kórnik-Poznań, http://teki.bkpan.poznan.pl/ (dostęp: 3.09.2018).

\section{SUMMARY}

\section{ARCHAEOLOGICAL STUDIES IN ZAREMBA MANOR HOUSE IN KALINOWA}

There is no possibility to talk about medieval Poland without Zaremba z Kalinowy family. Nowadays Kalinowa is a small village with gothic church and the XIX century looking palace surrounded by moat and lake from a north side. In XIV or beginning of XV century first manor house was build on the island. During our excavations in 2011 we discovered that in XV century new mansion was constructed on a mainland area. Inside there were beautiful late medieval tiled stoves, and rare artefacts (i.e. axe shaped badge) mostly known from large cities like Gdańsk or Kraków. In the XVII century Kalinowa was sold to Łubieńscy family. After that they build new palazzo in fortezza residence which was totally rebuilt in XVIII and XIX century. 